\title{
Wildlife Log on the Omo River
}

\author{
M.P. Ghiglieri
}

\begin{abstract}
After a canoe journey down the Omo River in southern Ethiopia, the author concludes that the river canyon is 'a viable ecosystem with a rich natural assemblage of large mammals'. But it is only the canyon's inaccessibility that protects the animals, and he wonders how long it will do so.
\end{abstract}

In September and October 1977, I took leave from a project on chimpanzees in Uganda's Kibale Forest to join an expedition down the Omo river, in southern Ethiopia, organised by Sobek Expeditions Inc. The stretch of river we floated was approximately $530 \mathrm{~km}$ long from Gibe Bridge, on the Gibe river, to the confluence of the Omo and Mui rivers. Only the last few kilometres were inside the Omo National Park. Because this main section of the Omo, protected and isolated by its deep, precipitous canyon, had received little attention from any zoologist, I kept a running log of all large animals seen in the river or along its banks as we travelled.

The river corridor is a special, islandtype microhabitat, which from a distant perspective has only one dimension, length. So I made no attempt to estimate the true density of any species. I made counts only while actually floating downstream in an inflatable boat; sightings off the river were not included in the counts. And because during most of my river time I was rowing a boat, sometimes through heavy rapids, I probably missed a few animals along the way. The counts tend to be conservative. However, independent counts made by Haile Seleshie, an official of the Ethiopian Wildlife Department, who was concerned with the numbers of hippo, crocodiles and African fish eagles in the canyon, showed results similar to mine; our hippo counts differed by only 2.2 per cent (1160 compared to 1186) and our fish eagle counts by about 15 per cent (67 compared to 78 ).

Several interesting patterns of abundance became apparent. The greatest hippo densities (up to $56.7 /$ hour) occurred in regions least accessible to humans. We saw none within $45 \mathrm{~km}$ of Gibe Bridge, where the canyon was most accessible to people; numbers dwindled again near Bale Bridge and fizzled out altogether in the open valley along the boundary of Omo National Park, where the Bodi, Bacha and Murci tribes live and hunt near the river. Most of the local people ate hippo meat, and human hunting pressure is probably the most important mortality factor of the Omo population.

Black and white colobus followed a similar pattern, except in the territories of the Bodi, Bacha and Murci. These Nilotic peoples seem little interested in hunting primates; they neither eat the meat nor wear animal skins for adornment. But the striking beauty of the colobus skins has led to their rarity in upstream parts of the canyon accessible to humans who can sell the skins with relative ease.

Anubis baboons were sighted almost everywhere, but vervet monkeys were rare. All ungulates were rare, even waterbuck. I suspect that these low numbers were the result of hunting pressure by both human and natural predators. The three lions we saw fled as we floated past. All large mammals were wary and behaved as though they were under human hunting pressure.

The crocodile pattern was almost the opposite of that of most other species. In the upper reaches of the canyon, where rapids were frequent, crocodiles were few and relatively small $(2.5 \mathrm{~m})$. Downst ream, in areas where the hippos had been decimated, crocodiles were more numerous, and where the Omo flowed into a wide valley and meandered in great loops the crocodiles were most numerous and large (up to $5 \mathrm{~m}$ ). A Murci informant who spoke Amharic admitted that the crocodiles were preying upon and eating humans regularly. On our final river day (day 16) a crocodile about $4 \mathrm{~m}$ long 
attacked our floating raft, but was driven off with an oar.

In summary, the Omo River canyon is presently a viable ecosystem with a rich natural assemblage of large mammals protected from decimation primarily by its topography. According to a local native of the highlands, even leopard are still common. Although the primeval aspects of may parts of the Omo canyon survive because of its isolation and inaccessibility, expanding populations on the periphery and the ever-increasing value of wild animal products, such as black and white colobus, !leopard and crocodile skins, hippo ivory and meat, will probably cause an increasing and unrelenting hunting pressure that can only have adverse effects on the populations. Currently there is nothing other than the canyon itself to discourage rifle-armed hunters and snare poachers; only tsetse flies limit human encroachment and habitat destruction. But how long these natural deterrents will preserve the pristine ecosystem of the Omo canyon is difficult to predict. At present it seems to be holding its own without the benefit of legislation or police.

Dr Michael P. Ghiglieri, PO Box 1976, Zephyr Cove, NE 89448, USA.

\section{The Ox-Pasture}

\section{Jennifer Rees}

Old 'unimproved' meadowland is increasingly scarce in Britain's intensively farmed land. Dr Jennifer Rees, an Open University tutor married to a farmer who breeds pedigree cattle on 100 acres in the Wye Valley, recently won the Sunday Times Kenneth Allsop Memorial Essay Competition with an essay that pinpoints the value of a 'great natural re-usable resource that can be replenished year after year at minimal cost'.

The Wye flows gently beside a meadow we call the 'Ox-Pasture'. This land saw no plough in my father's day, nor will it do so in my lifetime. On warm summer evenings I often walk by the river bank and watch the cattle feasting on the luscious grass, the mellow sunlight burnishing their chestnut-brown hides. They loop their tongues around the fragrant shoots and tear juicy mouthfuls from the turf; then, fat and sated, lie cud-chewing beneath the willow trees.

Just bury your face in a sweet succulent handful of this grass and you'll savour all summer's goodness. The vigorous perennial rye-grass Lolium perenne gives an abundant leafy crop year after year. Then there's the broad-headed cocksfoot Dactylis glomerata, a hard-stemmed grass with deep growing roots which can tap moisture running in the cracked soil six feet down. Walk on to the damp boggy parts of the field and you'll come upon Timothy grass Phleum pratense whose luxuriant soft-leaved heads thrive in all but the driest summers; and there's the delicate multi-headed meadow fescue Festuca pratensis.

Further searching will reveal a few wild strains of needle-leaved fescue, soft Yorkshire fog, and feathery-headed tufted hair-grass. The small-leaved white and red clovers yield up their energy and protein to the grazing animals; and there's even a place for some dandelions and comfrey which draw minerals from the deep soil and provide a rich supplement to the nutrition in the grass.

It's so peaceful in the lee of the dense hawthorn hedge that orange-tip butterflies and small tortoiseshells move freely in the sheltered air. Ladybirds, lacewing larvae and green-brindled crescent moth caterpillars hide among the leaves; wrens and hedge-sparrows are busy in the tangled branches. A lapwing rises from the marshy ground, glides in a wide circle and then accelerates upwards. 